\title{
The determinants of opting for the German group taxation regime with regard to taxes on corporate profits
}

\author{
Andreas Oestreicher $\cdot$ Reinald Koch
}

Received: 22 December 2008/Accepted: 29 October 2009/Published online: 20 November 2009

(C) The Author(s) 2009. This article is published with open access at Springerlink.com

\begin{abstract}
Forming a tax group for corporate and trade tax purposes in Germany has its advantages in terms of tax savings for the companies concerned. Depending on the profit situation, for certain companies these benefits were extended by the 2001 German corporate tax reform. However, setting up a tax group in Germany is also accompanied by certain disadvantages for the consolidated companies, resulting especially from the assumption of increased liability for subsidiaries' losses. The objective of this study is to investigate the factors determining the decision in favour of, or against, the formation of a tax group. A natural experiment arising from the 2001 German corporate tax reform allowed us to determine to what extent companies exploited the increased potential benefits of a tax group post reform. We test this finding employing firm-level data from the database AMADEUS. Our results show that the number of tax groups increased significantly with the introduction of the exemption method as from 01.01.2001. This result is especially apparent amongst companies benefiting from a tax group only post reform. Yet eligible companies which would have obtained tax benefits by entering into a tax group did not always choose this option. This applies in particular to parent companies with subsidiaries that are not wholly owned, and to small subsidiaries.
\end{abstract}

Keywords Corporate income tax - Group taxation - Organschaft . Firm-level data

JEL Classification $\quad \mathrm{H} 25 \cdot \mathrm{L} 2 \cdot \mathrm{K} 34$

Mathematics Subject Classification 91

\footnotetext{
A. Oestreicher $(\bowtie) \cdot$ R. Koch

Faculty of Economic Sciences, Institute for Domestic and International Taxation,

Georg-August-Universität Göttingen, Platz der Göttinger Sieben 3, 37073 Göttingen, Germany

e-mail: andreas.oestreicher@uni-goettingen.de
} 


\section{Introduction}

Forming a tax group for corporate and trade tax purposes ${ }^{1}$ has its merits in terms of tax savings for the companies concerned. This depends especially on the manner in which profits and losses are spread amongst the parent company and its subsidiaries and the way in which corporate dividends are taxed in the hands of the parent company. Taxation of corporate dividends changed significantly with the introduction of the exemption method for corporate shareholders in 2001. Therefore, one may expect that tax groups were opted for more frequently post reform. Empirical analysis confirms that the number of tax groups indeed increased, yet in relation to the total number of companies eligible it emerges that only some $30 \%$ actually made use of this option (see Sect. 3.2.1). We therefore seek to determine the factors that drive companies to form a tax group, or deter them from doing so.

Exploiting the possible benefits of corporate group taxation in Germany requires, among other things, the conclusion of a profit and loss transfer agreement between parent and subsidiary. This agreement obliges a subsidiary to transfer its entire profit to the controlling parent company. Where the subsidiary suffers losses, on the other hand, a profit and loss transfer agreement brings with it the obligation that the parent company has to compensate its subsidiary for losses incurred. Thus, in order to be able to benefit from the advantages a tax group offers, companies have to "pay" by assuming the risk of becoming liable for the losses of a subsidiary.

For purposes of assessing the tax impact on the choice of organizational form when establishing a corporate group, we analyse the possible cash flow effects under the two alternatives, comparing the benefits of a tax group with those of a standard group. $^{2}$ In order to identify situations where forming a tax group provides tax benefits, we exploit a natural experiment that arose from the 2001 German reform regarding the taxation of dividends in the hands of corporate shareholders. The changeover to the exemption method at the level of corporate shareholders had the effect of extending the scope for beneficial use of a tax group. In contrast to the tax credit method situation, creating a corporate tax group is now essential for offsetting parent company losses against profits of affiliated group companies, as resulted automatically under the tax credit system. Concluding a profit and loss transfer agreement, on the other hand, is costly and may lead to the further disadvantage that the scope of losses for which a parent company assumes liability is enlarged beyond the subsidiary's equity capital. As related costs are fixed in their nature and liability risks have particular effect where minority shareholders exist, these disadvantages turn out to deter above all small companies, as well as parent companies with subsidiaries that are not wholly owned.

Furthermore, we test empirically what kind of companies and to what extent eligible companies refrain from exploiting the tax advantages inherent to using a tax group. The percentage of such companies can be regarded as an indicator of how

\footnotetext{
${ }^{1}$ Such a tax group is referred to in German tax law as an "Organschaft". For the convenience of the international reader we adopt the term "tax group" in the text.

2 A "standard group" as referred to in this paper consists of a parent company and its majority-owned subsidiary which have not concluded a profit and loss transfer agreement and thus do not form a tax group.
} 
severe the load of assuming liability risks via profit and loss transfer agreement is perceived to be by eligible companies that would otherwise benefit from the formation of a tax group. Our investigation refers to the period from 1994 to 2003 and is limited to controlling companies organised in the legal form of a corporation. This limitation in scope is due to several reasons. Firstly, controlling companies organised as partnerships in practice hold less business relevance. Secondly, with respect to partnerships only few sets of data are available. Finally, important information with impact on the benefits of group taxation (e.g. income tax burden, income tax credit for trade tax paid) is not publicly available.

To our knowledge, this aspect regarding the influence of taxation on group structure has not up to now been subject to empirical research in the literature. Although the benefits of group taxation are subject to investigation in Weichenrieder and Mintz (2008), these authors address the question of what determines the ownership chains. Their focus is on third country conduit entities in German inbound and outbound foreign direct investment, in comparison with which exploitation of the benefits of a country holding presents a perfect alternative. Büttner et al. (2008) analyse strategic consolidation under formula apportionment. They investigate the question whether multijurisdictional enterprises strategically refrain from consolidation to preserve profit-shifting opportunities, by exploiting a quasi experiment that arose from another change in German tax law associated with the company tax reform in 2001. Desai et al. (2004) present results showing that whole ownership is most common when firms benefit from worldwide tax planning opportunities. Empirical evidence on the effects of tax loss set-offs shows that loss offset constraints affect corporate tax incentives (Altshuler and Auerbach (1990), Auerbach and Poterba (1986)). Gérard and Weiner (2003) investigate analytically the effect of introducing cross border loss offset and apportionment of the tax base, on inter alia the behaviour of a multijurisdictional firm. By the same token, based on a dynamic model of capital budgeting, Sureth and Üffing (2008) analyse the influence on corporate decisions of taxing multinationals under proposed concepts for corporate taxation in the EU. Oestreicher and Koch (2008) provide an assessment of the potential consequences for average corporate tax rates that would result from implementation of a Common Consolidated Corporate Tax Base (CCCTB) as proposed by the European Commission, and of possible methods for achieving an EU-wide loss-offset for multinational groups. Finally, the link between limited liability for losses and organizational form of companies is scrutinized. Gentry (1994) finds that publicly traded partnerships, eligible to escape from double taxation of income because their income is not subject to corporate tax, have less risky assets than corporations. However, this literature does not investigate factors determining the decision to opt for a group taxation system. This question continues to be one with particular German relevance as far as the profit and loss transfer agreement is concerned. However, the impact of the relevant corporate tax system (i.e. tax credit system vs. dividend exemption system) on the decision to form a tax group is also important with respect to other countries. This applies especially for EU member states which, for the most part, have changed their tax system to exempt corporate dividends in recent years (see Jacobs 2007: 115-125) and is of all the more significance in the event of the determination of income and the offsetting 
of corporate losses cross-border being harmonised in the EU (see European Court of Justice 2008a, b, 2005; Commission of the European Communities 2001, 2006, 2007; Endres et al. 2007: 104).

Our paper is set out as follows. Section 2 deals with the various tax consequences resulting from (the formation of) a tax group for purposes of taxes on corporate profits. Here, we theoretically analyse under what circumstances advantages would result from a tax point of view. In Sect. 3 the relevance of the tax group is subject to empirical investigation. We employ descriptive statistical methods to obtain a first impression of the extent to which group taxation has been applied in different settings over the period under review. Moreover, inductive statistical methods are applied in order to identify the relevant criteria governing the use of a tax group from a tax point of view. Based on these findings we discuss the principal results. Section 4 concludes the discussion.

\section{Application of the German group taxation regime}

\subsection{Outline of German group taxation provisions}

Corporations with their seat or place of management in Germany have, as separate legal entities, an unlimited liability to corporate tax. In the context of a corporate group this separate liability to tax has the effect that income of the individual group companies is determined and taxed in principle as if each company was legally and economically independent (separate entity theory). As a consequence, double or multiple taxation may arise where the profit of a subsidiary is distributed to parent companies. Furthermore, it is not possible to set off losses arising in a subsidiary against profits of the parent or of any other group company. Finally, intra-group transactions may result in taxable profits or losses.

In order to mitigate potential disadvantages compared to companies using permanent establishment structures, the German corporate tax law allows opting for a corporate fiscal unity. Under the system of fiscal unity the profits or losses of a (German) subsidiary ("the controlled company") are attributed to and taxed at the level of the parent company ${ }^{3}$ ("the controlling company"). ${ }^{4}$ The preconditions for this are that the controlled company is integrated into the business of the controlling company and commits itself by contract to transferring its entire profit to the controlling company, while the controlling company is obliged to compensate the controlled company for any losses incurred. For a tax group to be accepted, this agreement has to be concluded and carried out for a minimum period of 5 years. Integration into the business of the controlling company is deemed to exist if the

\footnotetext{
3 The territorial scope of the German group tax regime takes into account only domestic entities. This, however, does not mean that the members of a tax group must be in every case be domestic companies, but allows a domestic permanent establishment of a foreign company to be the head of a domestic tax group.

4 The term "controlling company" refers to the holding company meeting the precondition of functioning as the top company ("Organträger") of a German tax group ("Organschaft"); this company is not necessarily the ultimate parent company of the group as a whole ("Konzern") or even of its German subgroup.
} 
subsidiary's equity is held directly or indirectly to an extent of at least $50 \%$ by a German parent entity. ${ }^{5}$ Transfer of profits and compensation for losses does not relieve the controlled company from being a tax subject. The company is thus required to determine profits and losses as if the fiscal unity did not exist.

When comparing the relevant criteria involved in the decision to form a tax group during the period under review, 1994-2003, it has to be noted that the prerequisites for entering into a tax group as described above are applicable only since assessment period 2001. Up to this date it was necessary for the controlled company to be integrated into the controlling company not only financially, but also economically, and in terms of organization. Thus, in the course of the 2001 German corporate tax reform the requirements for entering into a tax group were clearly relaxed.

\subsection{Advantages in theory of forming a tax group before and after the 2001 tax reform}

Applying the rules of a tax group has its merits for the companies involved. Of greatest relevance is the immediate loss-offset among the members of the consolidated group. Further advantages include cost and interest savings regarding taxes that do not have to be withheld, as no withholding taxes arise on profits attributed to the controlling company. Moreover, more favourable compliance obligations and financial accounting requirements, and, in the event of group debt financing, trade tax savings as well as a comprehensive deductibility of participation related expenses, are also beneficial. ${ }^{6}$ The extent of these effects and the benefits of a tax group are dependent on various influencing factors. Besides, the profitability of the group companies, the extent of group finance, and corporate tax systems applied are of special relevance.

In this context, the 2001 German corporate tax reform was of particular significance concerning the benefits offered by a tax group. Until the 2000 assessment period inclusively, corporations were taxed according to the credit method in Germany. Since the 2001 assessment period the taxation of corporations has been carried out according to an exemption system. With regard to the period under review (1994-2003) it is therefore necessary, when discussing the benefits of a group tax system for income tax purposes, to differentiate between the tax advantages of the credit method and those of the exemption method.

Where relief from double taxation is achieved by exempting dividends received by a corporate shareholder (exemption system), multiple taxation of a subsidiary's profit is avoided effectively. This, however, also brings with it the negative consequence that expenses at the level of the parent company associated with the participation in economic terms may not be deducted from the profit of this

\footnotetext{
5 Thus, shares must also be taken into account which are held by an intermediate domestic or foreign partnership. Although permissible under German tax law, tax groups formed using a German branch of a foreign entity, however, are excluded from consideration in this study.

${ }^{6}$ A further (non-quantifiable) advantage results from an immediate profit transfer to the parent company under the profit and loss transfer agreement, whereas dividend payments may only be made for a previous year (Prinz 2003).
} 
Table 1 Exemption system loss-offset mechanism (standard group) as compared to a tax group

\begin{tabular}{|c|c|c|c|c|}
\hline \multirow[t]{2}{*}{ Parent } & \multicolumn{2}{|l|}{ Profits } & \multicolumn{2}{|l|}{ Losses } \\
\hline & Tax group & Standard group & Tax group & Standard group \\
\hline \multicolumn{5}{|c|}{ Subsidiary } \\
\hline Profits & $\begin{array}{l}\text { Attribution to the } \\
\text { profits of the } \\
\text { parent company }\end{array}$ & $\begin{array}{l}\text { Tax exempt income at } \\
\text { the level of the parent } \\
\text { company }\end{array}$ & $\begin{array}{l}\text { Attribution to (i.e. } \\
\text { setting off profits } \\
\text { against) the } \\
\text { losses of the } \\
\text { parent company }\end{array}$ & $\begin{array}{l}\text { Tax exempt income at } \\
\text { the level of the parent } \\
\text { company (i.e. no } \\
\text { offset against parent } \\
\text { company losses) }\end{array}$ \\
\hline Losses & $\begin{array}{l}\text { Attribution to (i.e. } \\
\text { setting off losses } \\
\text { against) the } \\
\text { profits of the } \\
\text { parent company }\end{array}$ & $\begin{array}{l}\text { Loss carry-back or loss } \\
\text { carry-forward at the } \\
\text { level of the subsidiary } \\
\text { (i.e. no offset against } \\
\text { profits of the parent } \\
\text { company) }\end{array}$ & $\begin{array}{l}\text { Attribution to the } \\
\text { losses of the } \\
\text { parent company }\end{array}$ & $\begin{array}{l}\text { Loss carry-back or loss } \\
\text { carry-forward at the } \\
\text { level of the subsidiary }\end{array}$ \\
\hline
\end{tabular}

company. Furthermore, profits and losses of the individual group companies cannot be set off intra-group.

Where the credit method is applied in order to protect companies from double taxation, multiple taxation of a subsidiary's profits is ruled out by means of a tax credit mechanism. As dividends are taxable at the level of the shareholder, profits may also be set off against parent company losses. Finally, participation expenses may be deducted at the level of the parent company. Setting off losses of a subsidiary, however, is not possible if no tax group has been set up.

As it can be seen from Tables 1 and 2, forming a tax group provides the companies concerned with tax benefits in three different profit/loss situations:

1. Income of the parent company $>$ zero, income of the subsidiary $<$ zero: due to the principle of separate entity it is basically not possible to offset tax losses of a subsidiary against profits of a parent company, irrespective of the system of corporate taxation applied. In the present case, where the subsidiary suffers losses, the group taxation regime for income tax purposes has the effect of creating interest advantages to the extent that, by way of group taxation, losses may be offset earlier than under the separate entity principle. ${ }^{7}$ These interest advantages from offsetting losses are, therefore, at their greatest where the losses may be offset immediately. ${ }^{8}$ For this to be possible it is sufficient for the positive income of the parent company to exceed the negative income of the subsidiary. This will often be the case, since positive income of further subsidiaries is included in the taxable income of the parent company. The longer it would take the subsidiary to offset losses against future positive

\footnotetext{
${ }^{7}$ Until 2003 under the exemption method expenses associated with dividend income were only deductible in the case of dividend income being received by the parent company. In the case of the subsidiary incurring losses, therefore, the parent company suffered no disadvantage even in the absence of a tax group.

${ }^{8}$ It is assumed that in the absence of group taxation the losses of the subsidiary may only be offset by way of loss carry-forward.
} 
Table 2 Credit system loss-offset mechanism (standard group) as compared to a tax group

\begin{tabular}{|c|c|c|c|c|}
\hline \multirow[t]{2}{*}{ Parent } & \multicolumn{2}{|l|}{ Profits } & \multicolumn{2}{|l|}{ Losses } \\
\hline & Tax group & Standard group & Tax group & Standard group \\
\hline \multicolumn{5}{|c|}{ Subsidiary } \\
\hline Profits & $\begin{array}{l}\text { Attribution to the } \\
\text { profits of the } \\
\text { parent company }\end{array}$ & $\begin{array}{l}\text { Taxable income at } \\
\text { the level of the } \\
\text { parent company }\end{array}$ & $\begin{array}{l}\text { Attribution to (i.e. } \\
\text { setting off profits } \\
\text { against) the losses } \\
\text { of the parent } \\
\text { company }\end{array}$ & $\begin{array}{l}\text { Taxable income at the level } \\
\text { of the parent company } \\
\text { (i.e. offset against parent } \\
\text { company losses) }\end{array}$ \\
\hline Losses & $\begin{array}{l}\text { Attribution to (i.e. } \\
\text { setting off losses } \\
\text { against) the } \\
\text { profits of the } \\
\text { parent company }\end{array}$ & $\begin{array}{l}\text { Loss carry-back or } \\
\text { loss carry- } \\
\text { forward at the } \\
\text { level of the } \\
\text { subsidiary }\end{array}$ & $\begin{array}{l}\text { Attribution to the } \\
\text { losses of the parent } \\
\text { company }\end{array}$ & $\begin{array}{l}\text { Loss carry-back or loss } \\
\text { carry-forward at the level } \\
\text { of the subsidiary }\end{array}$ \\
\hline
\end{tabular}

income, the higher the interest advantages. This effect arises to the same extent under the exemption method and under the credit method.

2. Income of the parent company $>$ zero, income of the subsidiary $>$ zero: where both the parent company and the subsidiary make profits, group taxation has withholding tax advantages both under the credit method and under the exemption method since profit transfer (as opposed to profit distribution) is not subject to tax at the time of transfer.

A further factor applying within the framework of the exemption method concerns expenses associated with tax exempted (domestic) profit distributions. In the assessment period 2001-2003 such expenses were only deductible within a tax group ${ }^{9}$ whereas according to the credit method the participation expenses of the parent company were also deductible in the absence of group taxation under the credit method. Under certain circumstances, however, the corresponding disadvantage of standard groups can be neutralized to a considerable extent by means of tax planning. ${ }^{10}$

3. Income of the parent company $<$ zero, income of the subsidiary $>$ zero: under the credit method dividends are taxable at the level of the shareholder. For that reason distributed earnings are also taxable, i.e. offsettable even in the absence of a tax group. ${ }^{11}$ Contrastingly, under the exemption method participation income is tax-free at the level of the parent company where the parent company operates in the legal form of a corporation. In this case, offsetting profits of the

\footnotetext{
9 The current legal status of this provision was introduced by law dated 22.12.2003 (BGB1. I 2003, p. 2840) and applied as from the assessment period 2004 onwards.

10 According to the "ballooning" strategy, as a rule no annual dividend payments are made for the period in which the participation expenses are incurred (normally the refinancing period). To a great extent this avoids the disadvantages caused by deductions for participation expenses being unavailable since deductibility required actual dividend payments ( $\$ 3 \mathrm{c}$ Income Tax Act [ITA]).

11 In order to take account of possible interdependencies between intra-group loss-offset and inter-period loss-offset at the level of the parent company, profit of the parent company is in principle regarded as positive income (after loss deduction) and loss as negative income (after loss carry-back).
} 
subsidiary against losses of the parent company is possible only if parent company and subsidiary have opted to form part of a tax group for corporate income tax purposes. Thus, under the exemption method group taxation (only) has advantages insofar as losses of the parent company can be offset at an earlier point in time than possible under the separate entity principle. These interest advantages arising from profit transfer are at their maximum where the profits of the subsidiary may be immediately offset against losses of the parent company. For this to be the case, it is sufficient for (negative) income of the parent company to exceed the (positive) income of the subsidiary or subsidiaries. Here, these interest advantages are dependent upon the time interval between the event of losses being offset intra-group and the point(s) in time where the profits of the subsidiary/parent can be offset against (own) losses/profits.

Furthermore, in the assessment periods 2001-2003, expenses associated with tax exempt (domestic) profit distributions are only deductible within a tax group. They represent an additional advantage of group taxation. Finally, an interest advantage arises through the existence of a tax group since profit transfers are not subject to withholding tax in this case.

Other advantages of a tax group are independent of the profit situation of the group companies and of the corporate tax system applied. This concerns especially relief with regard to trade tax. In the case of a subsidiary being loan financed intragroup, there is no requirement to calculate $50 \%$ of the interest payments associated with the loan into the trade tax base where a tax group exists between the subsidiary and the loan financing parent company. This results in a reduction of the effective trade tax burden where a tax group exists for trade tax purposes.

The benefits derived from a tax group under the exemption method and the tax credit method are summarized in Table 3. Comparison of the relevant factors reveals that the different criteria carry varying significance as far as the advantages of a tax group are concerned. The relevant individual factors are the level of income offsettable between parent company and subsidiary, the time interval between the offsetting of losses intra-group or inter-period, the level of participation expenses, the interest rate, and the rate of long-term inter-company loan. According to data from the German Bundesbank the average level of shareholder liability, however, is low. ${ }^{12}$ If it is taken into account that the disadvantage created by the limitation on deductibility of participation expenses can be minimized by way of tax planning, and the interest disadvantage resulting from the payment of withholding tax is limited to 1 year and is dependent on payment of dividends, we must assume that by far the greatest emphasis is on the advantage of immediate loss offset. Since the changeover to the exemption method, this has applied not only to the offset of losses of a subsidiary, but also in that a tax group allows the losses of a parent company to be offset against profits of its subsidiary or subsidiaries. Of lesser importance, however, are the financing of withholding tax payments and the fact that

\footnotetext{
12 For a representative average enterprise for the year 2002 the statistics of the German Bundesbank indicate long-term liabilities vis-à-vis affiliated companies to be $3.1 \%$ as a portion of the balance sheet amount, cf. Deutsche Bundesbank (2006).
} 
Table 3 Benefits of forming a tax group

\begin{tabular}{|c|c|c|c|}
\hline \multirow[t]{2}{*}{ Criteria } & \multicolumn{2}{|c|}{ Benefits of a tax group under the } & \multirow{2}{*}{$\begin{array}{l}\text { Implications of the change to the } \\
\text { exemption system as from } 2001 \\
\text { with regard to the benefits of a } \\
\text { tax group compared to the } \\
\text { taxation of the group as separate } \\
\text { entities }\end{array}$} \\
\hline & $\begin{array}{l}\text { Credit method (up to } \\
\text { 2000) }\end{array}$ & $\begin{array}{l}\text { Exemption } \\
\text { method } \\
\text { (as from 2001) }\end{array}$ & \\
\hline $\begin{array}{l}\text { Offsetting losses of a } \\
\text { subsidiary against profits of } \\
\text { a parent company }\end{array}$ & Yes & Yes & No fundamental change \\
\hline $\begin{array}{l}\text { Withholding taxes on intra- } \\
\text { group profit distributions }\end{array}$ & Yes & Yes & No fundamental change \\
\hline $\begin{array}{l}\text { Deductibility of expenses } \\
\text { associated against } \\
\text { participation income }\end{array}$ & No & Yes & $\begin{array}{l}\text { Improvement, in the case that the } \\
\text { subsidiary distributes profits }\end{array}$ \\
\hline $\begin{array}{l}\text { Offsetting profits of a } \\
\text { subsidiary against losses of } \\
\text { the parent company }\end{array}$ & No & Yes & $\begin{array}{l}\text { Broadening of application under } \\
\text { the exemption method; benefits } \\
\text { dependent upon existence of } \\
\text { pre-contractual losses }\end{array}$ \\
\hline $\begin{array}{l}\text { Multiple taxation of intra- } \\
\text { group interest payments }\end{array}$ & Yes & Yes & $\begin{array}{l}\text { No fundamental improvement; } \\
\text { disadvantages may even result } \\
\text { as a selective forming of a tax } \\
\text { group for trade tax purposes } \\
\text { is no longer possible }\end{array}$ \\
\hline
\end{tabular}

participation expenses are not tax deductible. Finally, taking the empirical data of the German Bundesbank for a representative enterprise, the obligation to calculate interest payments on long-term loan into the trade tax base plays only a minor role.

\subsection{Disadvantages of forming a tax group}

Meeting the prerequisites of a tax group brings not only advantages. Concluding a profit transfer agreement may, for example, be costly, especially in the case that compensation payments to minority shareholders have to be ascertained. Moreover, a profit and loss transfer agreement brings with it the risk of being held liable for claims vis-à-vis controlled companies. Further disadvantages may arise if the controlled company carries forward losses that accrued prior to formation of a tax group. Finally, there may also be disadvantages with respect to trade tax if the necessary allocation of the tax base for trade tax purposes would result in a higher tax burden compared to the attribution of profits and losses under the separate entity principle.

Whereas the advantages of forming a tax group can be traced back to its tax treatment, the disadvantages result primarily from civil law consequences of the profit and loss transfer agreement. From a tax perspective, setting up a tax group can be disadvantageous above all where the subsidiary carries forward losses which, in the absence of a tax group, could be set off against positive income of this company (Table 4, item 1). In addition, disadvantages may arise through allocation for trade tax purposes if the trade tax base is allocated to a location with a higher trade tax levying rate (Table 4 , item 2 ). 
Table 4 Disadvantages of forming a tax group

\begin{tabular}{|c|c|c|c|}
\hline \multirow[t]{2}{*}{ Criteria } & \multicolumn{2}{|c|}{ Disadvantages of a tax group under the } & \multirow{2}{*}{$\begin{array}{l}\text { Implications of the change to the } \\
\text { exemption system as from } 2001 \\
\text { with regard to the benefits of a } \\
\text { tax group compared to the } \\
\text { taxation of the group as separate } \\
\text { entities }\end{array}$} \\
\hline & $\begin{array}{l}\text { Credit method } \\
\text { (up to 2000) }\end{array}$ & $\begin{array}{l}\text { Exemption } \\
\text { method } \\
\text { (as from 2001) }\end{array}$ & \\
\hline Pre-contractual losses & Yes & Yes & $\begin{array}{l}\text { No fundamental improvement; } \\
\text { disadvantages exist also in the } \\
\text { case that profits of the } \\
\text { subsidiary may be offset } \\
\text { against losses of the parent } \\
\text { company (see Table } 3 \text {, item } 4 \text { ) }\end{array}$ \\
\hline $\begin{array}{l}\text { Allocation advantages/ } \\
\text { disadvantages with } \\
\text { respect to trade tax }\end{array}$ & Yes & Yes & $\begin{array}{l}\text { No fundamental improvement; } \\
\text { disadvantages may even result } \\
\text { as a selective forming of a tax } \\
\text { group for trade tax purposes is } \\
\text { no longer possible }\end{array}$ \\
\hline
\end{tabular}

Where a subsidiary carries forward losses, forming a tax group has the effect of "freezing" these loss carry-forwards for its duration. Although, after the tax group has been terminated, losses from the pre-transfer agreement period can be brought back into play, taking into account a minimum term of 5 years and assuming an interest rate of $5.5 \%$ the devaluation of the loss carry-forwards resulting from the time lapse amounts to more than $23 \%$. Closer scrutiny reveals, however, that this devaluation is linked with the tax group only if the subsidiary has positive income that could have been offset under the terms of a tax group. But even in this case disadvantages arise only if the profits of the subsidiary cannot be set off against losses of the parent company. In the event that the parent company suffers losses the tax group merely prevents prior losses from being shifted to the level of the parent company.

It is fair to assume, however, that the main hindrances to setting up a tax group are the disadvantages of a profit and loss transfer agreement arising from civil law, in particular the associated liability risks. Within the framework of a profit and loss transfer agreement the controlling company has to assume any annual financial losses incurred by the controlled enterprise during the term of the contract. This applies only if the financial losses cannot be compensated by other reserves set up by the controlled company while the agreement is effective. The dependent company further undertakes to refrain from waiving this compensation claim for a period of 3 years following the termination of the agreement. Taking into account that the profit and loss transfer agreement is concluded for a minimum period of 5 years it becomes apparent that this element of a profit and loss transfer agreement constitutes a considerable risk for the controlling enterprise.

A further problem arises from the corporate law provisions regarding the creation of a contractual group. At the top of the list in this respect are the possible compensation payments to minority shareholders which have to be paid either upfront or as a guaranteed dividend, irrespective of whether the controlled company 
is profitable or suffers losses. Moreover, concluding a profit and loss transfer agreement requires several actions including, but not limited to, designing the contract, determining compensation payments to minority shareholders, if necessary, notarizing approval by the shareholders assembly, entering the agreement in the commercial register, drawing up a board members' report as well as performing an audit by certified accountants including a relevant report. The total costs of fulfilling these requirements may add up to significant amounts.

\subsection{Interim conclusions}

The above discussion of the prerequisites as well as the advantages and disadvantages from entering into a tax group gives rise to the following expectations with regard to the advantageousness of the tax group and its application over the course of the period under review:

1. Following the enactment of the 2001 tax reform the number of group companies subject to group taxation should have risen since the advantages of the tax group have been extended and, at the same time, the prerequisites reduced.

2. In comparison to the years prior to 2001 it is to be expected that from 2001 amongst the newly formed tax groups the proportion of parent companies reporting own losses increased.

3. Relaxing the group taxation prerequisites should have a differing effect on small and large subsidiaries assuming that the stricter prerequisites prior to the reform deterred especially small companies from entering into a tax group. The same applies to subsidiaries with minority shareholders for which the verification of organizational and economic integration, as required prior to the reform, can be assumed to have posed greater difficulties than for wholly owned subsidiaries.

4. Losses carried forward at the level of the subsidiary should deter groups from forming a tax group. This applies in particular when both the parent company and the subsidiary report profits.

5. Loan financing by the parent company should on average be of minor relevance for forming a tax group. Only in the case of subsidiaries financed with parent company debt to an extraordinarily great extent, trade tax deductibility of interest expenses may turn out to be an impacting factor.

6. In view of the costs associated with concluding a profit and loss transfer agreement, the benefits of a tax group are expected to be exploited the more frequently, the larger the (financial capacity of) the group companies.

7. In view of the costs that may arise in terms of minority shareholders' entitlements arising from forming a contractual group, it is to be expected that tax groups are more common where the participation is $100 \%$.

8. The liability risks associated with forming a tax group may be expected to function as a deterrent to including subsidiaries that indicate an increased risk of incurring losses even though the tax benefits of a tax group are increased at the same time. However, these tax benefits can compensate the parent company 
not to full extent for the costs associated with liability for definite losses incurred at the level of the subsidiary.

Due to data restrictions not all of these eight hypotheses can be subjected to empirical verification. This applies to hypotheses 4 and 5, whereas hypothesis 8 can be tested only indirectly. Hypotheses 2 and 3 indicate that the 2001 tax reform had particular impact for (1) groups in which the subsidiary reports profits, while the parent company suffers losses, (2) small subsidiaries and (3) subsidiaries with minority shareholders. When analysing the effect of the tax reform on the decision to opt for a tax group or not, these differences call for a distinct consideration of the individual groups.

\section{Empirical results}

\subsection{Data}

Employing the database AMADEUS, ${ }^{13}$ the following empirical analysis of the criteria for forming a tax group for corporate tax purposes is based on company micro-data. AMADEUS is a comprehensive pan-European database containing financial information on some nine million public and private companies in 38 European countries and is made available by the private database provider Bureau van Dijk. It contains standardised (consolidated and unconsolidated) annual accounts (for up to 10 years), financial ratios, activities and ownership information for the companies included.

The part of the database relevant for this study covers German parent companies and their domestic subsidiaries. A parent-subsidiary relationship is deemed to exist if the subsidiary is held (directly or indirectly) to an extent of at least $50 \%$ by a German parent company. ${ }^{14}$ According to this definition, 22,142 domestic groups are identified comprising a total of 61,707 group companies. Since the information available for the companies covered by AMADEUS is not complete in all cases further limitations are necessary when applying the data. Information with regard to profit and loss transfer agreements does not form part of the AMADEUS database. Therefore, the existence of a tax group for income tax purposes has to be identified on the basis of its visible features. To this end, we assume that a tax group exists where the profit or loss of the subsidiary for the period is transferred in full to a parent company. Profit transfers and assumption of losses are shown in the extraordinary income. Thus it is possible to assume a controlled company where the subsidiary's profit or loss for the period is shown as zero whereas the result of ordinary business activities is above or below zero. ${ }^{15}$ Therefore, the investigation

\footnotetext{
13 Our analysis is based mainly on update 125 (February 2005). Accounting data for 2003 was added from update 179 (January 2009) as this is not provided to full extent in update 125. Furthermore, shareholding information from update 64 (January 2000) is employed in order to identify group structure changes.

14 This selection is based on the German tax group rules ( $\$ 14$ Para. 1 Corporation Tax Act [CTA]).

15 Drawing on federal statistics on corporate taxation for 2001 , a test revealed that this assumption of the existence of controlled companies was correct in 87 out of 94 cases $(92.55 \%)$. Out of a total of 1,010 companies not belonging to a tax group only 31 (3.07\%) were wrongly assumed to be controlled companies.
} 
included only those subsidiaries for which at least one unconsolidated financial statement for the period 1994-2003 was available showing both the income from ordinary business activities and the profit or loss on the year.

As far as the controlling company is concerned, it is presumed that the tax group relationship exists to the directly participating enterprise in each case. Since a breakdown of the financial results regarding finance income and financing costs is not available in AMADEUS, precise identification is not possible. However, any incorrect attribution associated with this may be assumed to be of only minor significance as the tax group relationship to subordinated companies is not devoid of legal difficulties where shareholders are involved. Furthermore, $76.06 \%$ of the subsidiaries included in the panel are held directly by the top parent company in any case.

For purposes of checking whether the results are distorted in that companies are included in the panel while belonging to a group in 2003 but not in previous years, a subpanel (Panel 2) is employed in supplementary manner. This subpanel comprises only those companies that are (a) also included in update 64 of AMADEUS (January 2000) and (b) controlled by the same company in both updates. This procedure allows that the relevant controlling company may be assumed to be identified throughout the entire period under review. ${ }^{16}$

One objective of the regression analysis is the identification of potential treatment effects resulting from the 2001 company tax reform. This requires a further reduction of the company panel applied. Included in our regression are only those companies belonging to Panel 1 or Panel 2 for which the feature of being a controlled company can be assessed for at least 1 year in the period prior to the reform (1994-2000) and 1 year following the reform (2001-2003). The resulting panels applied to our regression model comprise 660 subsidiaries (Panel 1) and 120 subsidiaries (Panel 2), respectively.

\subsection{Descriptive statistics}

\subsubsection{Development of the number of controlled companies over the period under review}

The combination of enhanced conditions favouring formation of a tax group and relaxation of the prerequisites of a tax group for corporate tax purposes suggests that the number of controlled companies (subsidiaries belonging to a tax group) will have risen as from assessment period 2001. In order to obtain a first impression of the reform's impact, the data basis was analysed with reference to the individual years of the period under review (1994-2003). In so doing we differentiated between the two test-panels discussed above. Panel 1 contains all companies which according to the participation details provided in update 125 of the AMADEUS database were financially integrated into a parent company, whereas Panel 2 further limits the extent of the panel to those subsidiaries controlled by the same company

\footnotetext{
16 In general, employing shareholder information from a year nearer to the beginning of the period under consideration would best serve this purpose; this is, however, countered by the smaller number of companies included in previous updates.
} 


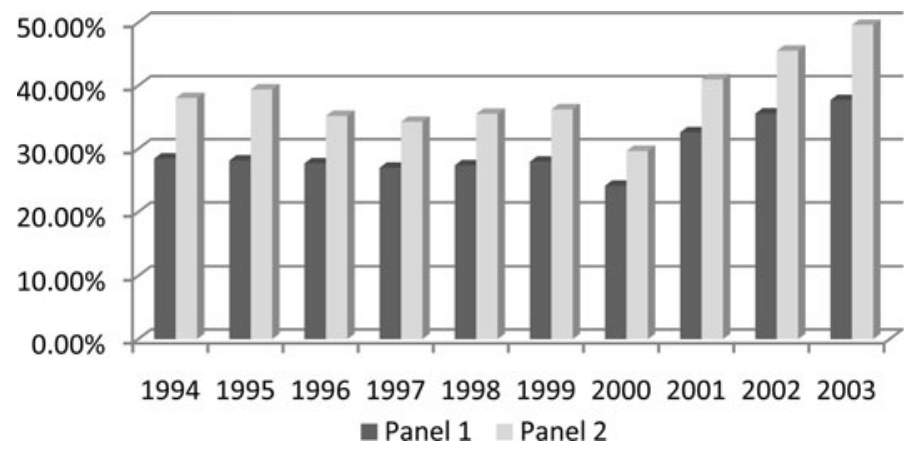

Fig. 1 Relative share of controlled companies over the period under review. Source: Calculations based on AMADEUS (125). This figure depicts the relative share of companies included in Panel 1 and Panel 2 for which the option to form a tax group has been used (controlled companies)

both in update 64 and in update 125. In order to avoid distortions resulting from an increased number of enterprises contained in the sample as well as the higher proportion of financial statements covered in more recent years, we traced the development of the relative proportion of controlled companies to all subsidiaries covered by AMADEUS. The year-by-year result of this analysis is shown for both test-panels in Fig. 1.

Figure 1 indicates in the case of both panels a slight reduction in the relative proportion of controlled companies for the period 1994-2000 and a marked increase in the years 2001-2003. The tendency of this development corresponds to the results of the federal statistics on corporate tax. However, this observation does not give any explanation as to whether this development is due to the extended tax advantages or to the reduced tax group prerequisites as applicable since 2001 .

\subsubsection{Decision to opt for a tax group: advantages/disadvantages associated with intra-group loss offset}

Tax groups give rise to advantages where a set-off of losses is possible between group companies. It may therefore be expected that in comparison to companies belonging to a standard group controlled companies in general show losses more frequently. For parent companies reporting losses, on the other hand, forming a tax group was not necessary in order to set off losses against profits of a subsidiary under the credit method. For the latter constellation, therefore, no major differences between standard groups and tax groups are to be expected. For purposes of categorizing groups according to the income of the group companies, the standard groups and the tax groups included in the database were examined with respect to the distribution of profits and losses between parent company and subsidiary. To this end the following four scenarios for each year were distinguished. Hereby, income is defined in the case of the subsidiary as ordinary profit, and in the case of the parent company as ordinary profit less profit or loss transferred, or dividends distributed, ${ }^{17}$ by the subsidiary.

\footnotetext{
17 Dividend distributions are estimated by comparing the profit and loss for the period with the change in equity (other than capital stock).
} 
1. Income of the parent company $>$ zero, income of the subsidiary $>$ zero (Profit/ Profit),

2. Income of the parent company $>$ zero, income of the subsidiary < zero (Profit/ Loss),

3. Income of the parent company < zero, income of the subsidiary > zero (Loss/ Profit),

4. Income of the parent company $<$ zero, income of the subsidiary $<$ zero (Loss/ Loss).

Our findings demonstrate that in the periods prior to the 2001 tax reform (19942000), losses only at the level of the subsidiary can be observed more commonly in controlled companies belonging to a tax group than in the case of subsidiaries belonging to a standard group (Profit/Loss). If the losses are incurred only by the parent company no major differences are to be observed between companies belonging to a tax group and standard groups. This scenario (Loss/Profit) can also be observed more frequently in the case of a tax group, however, while scenarios with both the parent and the subsidiary earning profits (Profit/Profit) or losses (Loss/Loss) occur more frequently in standard group constellations. On closer consideration it may well be puzzling that almost half of the cases fall into the category where there is no loss-offset between the companies. But before drawing the conclusion that intra-group loss-offset must be relatively insignificant for setting up of a tax group, one should take into account the fact that the observations refer to individual years while a profit and loss transfer agreement must be concluded for a minimum period of 5 years. Furthermore, it must be remembered that the results of our analysis reflect the results of past years while the decision to form a tax group is based on expectations.

Under the exemption method offsetting losses of the parent company against profits of a subsidiary is only possible within a tax group. It is therefore to be expected that in comparison with firms belonging to a standard group parent companies report losses more commonly in the context of a tax group. Besides, offset of losses of the subsidiary against profits of the parent company necessitates that a tax group exists between the companies. The frequency of the different profit and loss situations in standard groups and tax groups after the 2001 tax reform is shown in the lower section of Table 5.

These results for the period 2001-2003 demonstrate that a distribution in which the losses are reported at the level of the parent companies and profits at the level of the subsidiaries is more common in the case of tax groups (Loss/Profit). Where a parent company reports profits, losses of a subsidiary are also observed more frequently under the provisions of a tax group (Profit/Loss). The case of both parent company and subsidiary reporting profits is more commonly observed among standard groups. The same applies where both parent company and subsidiary report losses.

Loss carry forwards at the level of the subsidiary should restrain companies from entering into a tax group. This holds true in particular where both the parent company and the subsidiary are profitable. In order to differentiate existing tax groups according to the presence of accrued losses to be carried forward at the level 
Table 5 Frequency (in \%) of different profit/loss situations in standard groups and tax groups

\begin{tabular}{llllll}
\hline Type of group & Time period & Profit/Profit & Profit/Loss & Loss/Profit & Loss/Loss \\
\hline Standard groups & $1994-2000$ & $\mathbf{0 . 5 3 3 8}$ & 0.1526 & 0.2189 & $\mathbf{0 . 0 9 4 7}$ \\
Tax groups & $1994-2000$ & 0.3913 & $\mathbf{0 . 2 7 7 4}$ & $\mathbf{0 . 2 7 9 5}$ & 0.0518 \\
Standard groups & $2001-2003$ & $\mathbf{0 . 5 5 3 7}$ & 0.1561 & 0.1914 & $\mathbf{0 . 0 9 8 9}$ \\
Tax groups & $2001-2003$ & 0.3965 & $\mathbf{0 . 2 4 1 7}$ & $\mathbf{0 . 2 8 5 6}$ & 0.0762 \\
\hline
\end{tabular}

Source: Calculations based on AMADEUS (125). This table summarizes the frequency (in $\%$ ) of the different profit/loss situation in standard groups and tax groups before and after the 2001 tax reform. To this end the number of observations showing the respective profit/loss situation is set in relation to the overall number of observations within each of the four sub-samples. The frequencies total 1 in each line. Bold values indicate the more frequent observations

of the controlled companies, amounts of an inter-period loss-carry forward were assessed on the basis of negative equity capital other than capital stock. For purposes of excluding any endogenous influence, only subsidiaries that did not form part of a tax group in 2000 were taken into consideration. Our calculations reveal that within this panel (tax groups formed in the new setting) subsidiaries displaying negative equity capital (other than capital stock) function as controlled companies in $17.81 \%$ of all cases, whereas the proportion of companies displaying positive equity capital (other than capital stock) amounts to $35.13 \%$.

\subsubsection{Decision to opt for a tax group: costs of implementation}

Concluding a profit and loss transfer agreement requires numerous resolutions, reports, audits, and registration of this agreement with the commercial register ( $\S 293,294$ CTA). As most of these costs do not depend on company size, we expect the probability of the existence of a tax group to rise with the size of the group companies. In order to investigate the relationship between tax group and size of group companies, we categorized all (tax and standard) groups of companies according to the size of the group as a whole and the size of the subsidiaries. For the size of subsidiaries, we took the determinants employed for size differentiation in preparing financial statements as our categorization criteria; our categorization criterion for group size was the number of group companies. ${ }^{18}$

It emerges that the ratio of controlled companies to all subsidiaries of a consolidated group increases the larger the size of the subsidiaries. The proportion of controlled companies is $56.85 \%$ where large subsidiaries are involved, whereas medium-sized subsidiaries and small subsidiaries form part of a tax group in only 51.15 and $39.91 \%$, respectively. A comparable picture emerges when the size of the entire group is categorized.

Moreover, a profit and loss transfer agreement must include provisions regarding compensation and settlement in cash or kind ( $\S 304,305$ CTA). These requirements necessitate evaluation of the companies in light of their future profit potential, give rise to costs, and in practice are often subject to long-winded

\footnotetext{
18 A small group consists of up to five group companies, whereas a medium-sized group consists of up to 50 and a large group of more than 50 group companies.
} 


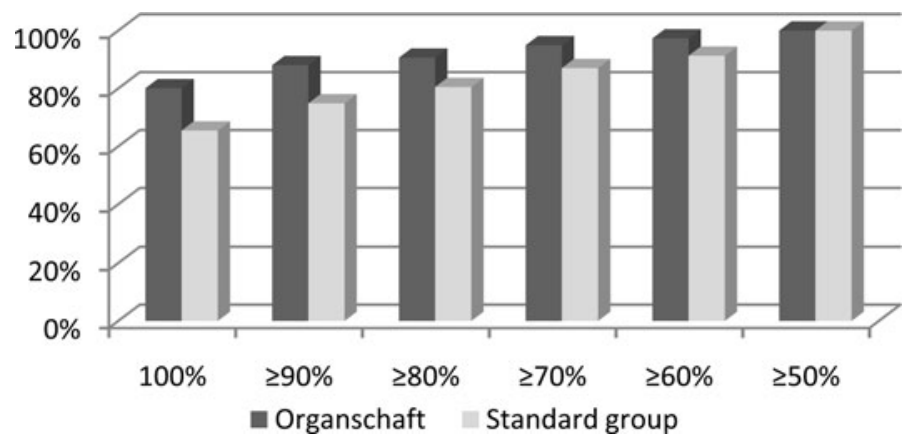

Fig. 2 Participation quotas in standard groups and tax groups. Source: Calculations based on AMADEUS (125). This figure depicts the share of subsidiaries in standard groups and tax groups for which the participation quota exceeds the respective thresholds

disputes, hence deterring parties from forming a tax group (Orth 2005; Prinz 2003). Therefore, the expectation is that companies are more frequently held by one sole shareholder where the controlled company forms part of a tax group rather than belonging to a standard group of companies. For the purpose of getting a first impression of this effect, we determined the proportions of tax groups and standard groups with respect to different quantitative threshold values. Figure 2 depicts these proportions.

It becomes clear that $80 \%$ of the controlled companies forming part of a tax group are held to $100 \%$ by the controlled company or a third group company, i.e. minority shareholders exist in only $20 \%$, whereas in the context of a standard group the proportion of companies held by the parent company to $100 \%$ accounts for merely $66 \%$. The overall average holding of group companies by parent companies emerges as $96 \%$ in the case of controlled companies (whereas this percentage amounts to $91 \%$ in the case of subsidiaries belonging to a standard group).

\subsubsection{Decision to opt for a tax group: liability risks}

A fundamental disadvantage militating against the creation of a tax group is the liability for losses incurred by the controlled company that results from conclusion of a profit and loss transfer agreement. The degree of this liability risk is dependent upon both the operative and financial risk of the subsidiary and the legal form of the controlling company.

For purposes of capturing the business risk and the risk associated with the capital structure of the subsidiary we determine the percentage of controlled companies subject to the equity ratio and the standard deviation regarding the return on sales (Table 6). In order to avoid endogenous effects we refer to the equity ratio as prevailing prior to the possible implementation of a tax group. The values presented in Table 6 reflect the frequency of tax groups newly founded after 2000, with reference to the impact of the equity ratio.

The two sets of calculations show only minor variations. Although the percentage of controlled companies ranges from 38.65 to $50.00 \%$ among the various quantiles 
Table 6 Frequency of tax groups in sub-samples with differing equity ratios and standard deviations of the return on sales

\begin{tabular}{|c|c|c|c|c|c|c|c|c|c|c|}
\hline \multirow{2}{*}{$\begin{array}{l}\text { Financial } \\
\text { ratios }\end{array}$} & \multicolumn{10}{|c|}{ Parameter value } \\
\hline & $\begin{array}{l}10 \% \\
\text { Quantile }\end{array}$ & $\begin{array}{l}20 \% \\
\text { Quantile }\end{array}$ & $\begin{array}{l}30 \% \\
\text { Quantile }\end{array}$ & $\begin{array}{l}40 \% \\
\text { Quantile }\end{array}$ & $\begin{array}{l}50 \% \\
\text { Quantile }\end{array}$ & $\begin{array}{l}60 \% \\
\text { Quantile }\end{array}$ & $\begin{array}{l}70 \% \\
\text { Quantile }\end{array}$ & $\begin{array}{l}80 \% \\
\text { Quantile }\end{array}$ & $\begin{array}{l}90 \% \\
\text { Quantile }\end{array}$ & $\begin{array}{l}100 \% \\
\text { Quantile }\end{array}$ \\
\hline $\begin{array}{l}\text { Return on } \\
\text { sales (SD) }\end{array}$ & 0.3865 & 0.4220 & 0.4929 & 0.4752 & 0.4752 & 0.4610 & 0.4787 & 0.4397 & 0.5000 & 0.4733 \\
\hline Equity ratio & 0.3860 & 0.2537 & 0.3784 & 0.3676 & 0.2813 & 0.2879 & 0.3788 & 0.4035 & 0.3088 & 0.2857 \\
\hline
\end{tabular}

Source: Calculations based on AMADEUS (125). We divided the subsidiaries in our sample into ten groups with regard to standard deviation of return on sales and the equity ratio. This table illustrates the percentage of controlled companies in any of these sub-samples

of the standard deviation regarding the return on sales, no increase can be observed for the higher and smaller values of this measure. The same applies in principle to the equity ratio as prevailing prior to forming a tax group.

Where the parent company and the subsidiary form part of the same industry, the cyclical development affects both companies in a comparable way. In these cases the advantageousness of a tax group is expected to be limited as uniform influence of the business cycle increases the probability that parent company and subsidiary both produce positive or negative income. By the same token, in the absence of diversification an economic downturn gives rise to increased liability risk. For purposes of analyzing the possible interrelation between tax group and the industry in which parent company and subsidiary operate we determined the proportion of companies opting for a tax group within groups belonging to the same business sector in comparison with standard groups. It is revealed that in standard groups parent company and subsidiary operate in the same industry in $37.45 \%$ of all observations, whereas the corresponding proportion in tax groups amounts to $31.59 \%$.

\subsection{Inductive statistics}

\subsubsection{Regression models}

Our regression analysis looks at two issues are addressed. Firstly, we investigate how companies balance in their decision tax advantages and non-tax disadvantages resulting from entering into a tax group. Secondly, we test whether, and if so to what extent, the 2001 tax reform has affected this company decision. Two different treatment effects are possible in this context as the reform has, on the one hand, increased the tax advantages of a tax group and, on the other hand, reduced the tax group prerequisites. In the course of this latter adjustment, the non-tax costs have risen, while the number of subsidiaries not eligible for inclusion in a tax group has declined. Given this quasi-experimental setting we apply a difference-in-difference approach for our analysis. ${ }^{19}$ To this end, we split up our observations for each

\footnotetext{
${ }^{19}$ See also Overesch and Wamser (2009) for an application of a difference-in-difference approach to explain tax reform effects.
} 
company into a first observation referring to years 1994-2000 and a second observation referring to years 2001-2003. For purposes of distinction we include the post reform dummy REFORM, which takes the value of one if the observation refers to the post-reform period.

For our analysis we use a logistic regression model based on the dependent variable TG. This variable takes on the value of one if a subsidiary meets the requirements of a controlled company for corporate tax purposes in at least 1 year during the relevant period under consideration (1994-2000 or 2001-2003), otherwise the value is zero. As described earlier, we assume that a tax group exists where the profit or loss of the subsidiary for the period is transferred in full to a parent company. Profit transfers and assumption of losses are shown in the extraordinary income. Thus it is possible to assume the presence of a controlled company where the subsidiary's profit or loss for the period is shown as zero whereas the result of ordinary business activities is above or below zero. As far as Panel 1 is concerned TG is assigned the value of one in $32 \%$ of all cases prior to the reform and $49 \%$ of all cases after the reform. The corresponding values for Panel 2 amount to 42 and $58 \%$, respectively. Based on the discussions above it should follow that the use of a tax group is subject to a number of different tax and non-tax parameters. For the purposes of detailed analysis the following independent variables are employed (Table 7).

MINORITY, MIN_SH, ENTERPRISE and GROUPSIZE reflect the fact that costs associated with concluding a profit and loss transfer agreement (e.g. costs due to legal disputes with regard to compensation payments if minority shareholders are involved) may deter especially small companies and groups from entering into a tax group. Moreover, liability risks have particular impact where minority shareholders exist as compensation payments have to be paid even if the controlled company suffers losses. The interaction between costs and risks resulting from the existence of minority shareholders and the subsidiary size is further accounted for by including the interaction term MIN_SH*ENTERPRISE into our model. According to the hypotheses 6 and 7 set out in Sect. 2.4 we expect negative coefficients to be estimated for all of these variables. PL and LP_30/LP_50/LP_80 stand for the tax advantages from intra-group loss-offset arising in the context of a tax group. High values of PL are associated with benefits arising both prior to and after the 2001 tax reform, whereas in the case of the different specifications of LP taking a value of one, advantages arise from entering into a tax group especially in 2001 and subsequent years. ROS (SD) and SAME INDUSTRY account for the liability risks associated with concluding a profit and loss transfer agreement, which are assumed to reduce the probability for forming a tax group (see hypothesis 8 in Sect. 2.4).

The regression model applied does not include variables reflecting tax group disadvantages in the presence of pre-contractual losses, the increased liability risk in case the subsidiary has a small equity ratio, and business-cycle effects. The first two of these effects are, in the way they are included in our data, expected to be dependent on the existence of a tax group and are therefore excluded for reasons of endogeneity. Including a variable reflecting the economic performance picks up the influence of the economic downturn in the years 2001 and 2002 on the decision as to whether or not to opt for a tax group. However, such a variable is highly negatively 
Table 7 Descriptive statistics on the dependent and independent variables (Panel 1)

\begin{tabular}{|c|c|c|c|c|c|c|}
\hline Name & Description & Scale & Mean & SD & Min. & Max. \\
\hline TG & $\begin{array}{l}\text { Takes on the value of one if a subsidiary meets } \\
\text { the requirements of a controlled company for } \\
\text { income tax purposes in at least one year } \\
\text { during the relevant period under } \\
\text { consideration (1994-2000 or 2001-2003), } \\
\text { otherwise the value is zero. }\end{array}$ & Dummy & 0.40 & 0.49 & 0.00 & 1.00 \\
\hline REFORM & $\begin{array}{l}\text { Takes the value of one if the observation refers } \\
\text { to the post-reform period. Otherwise a value } \\
\text { of zero is assigned. }\end{array}$ & Dummy & 0.50 & 0.50 & 0.00 & 1.00 \\
\hline ENTERPRISE & $\begin{array}{l}\text { Takes on the value of one if according to the } \\
\text { Commercial Code the subsidiary is classified } \\
\text { as a small company. Otherwise the value of } \\
\text { this variable is zero. }\end{array}$ & Dummy & 0.31 & 0.46 & 0.00 & 1.00 \\
\hline GROUP SIZE & $\begin{array}{l}\text { This variable reflects the number of group } \\
\text { companies and is represented in terms of its } \\
\text { natural logarithm. }\end{array}$ & $\ln$ & 2.48 & 1.45 & 0.69 & 6.15 \\
\hline MINORITY & $\begin{array}{l}\text { This variable takes on the value of one if } \\
\text { minority shareholders exist. Where the } \\
\text { parent company is a sole shareholder, zero is } \\
\text { assigned. }\end{array}$ & Dummy & 0.36 & 0.48 & 0.00 & 1.00 \\
\hline MIN_SH & $\begin{array}{l}\text { This variable measures the share in the capital } \\
\text { held by minority investors. }\end{array}$ & Numeric & 7.63 & 14.35 & 0 & 50 \\
\hline PL & $\begin{array}{l}\text { Measures the relative frequency of cases (in } \\
\% \text { ) occurring in the period under review } \\
\text { (1994-2003) where the parent company } \\
\text { income is positive whereas the subsidiary } \\
\text { income is negative. }\end{array}$ & Numeric & 0.18 & 0.31 & 0.00 & 1.00 \\
\hline LP_30 & \multirow{3}{*}{$\begin{array}{l}\text { Takes the value of one if the frequency of } \\
\text { cases (in \%) where the parent company } \\
\text { income is negative whereas the subsidiary } \\
\text { income is positive exceeds the respective } \\
\text { threshold }(30 \%, 50 \%, 80 \%) \text { in the period } \\
\text { under review }(1994-2003) .^{\text {a }}\end{array}$} & \multirow[t]{3}{*}{ Dummy } & 0.34 & 0.48 & 0.00 & 1.00 \\
\hline LP_50 & & & 0.28 & 0.45 & 0.00 & 1.00 \\
\hline LP_80 & & & 0.16 & 0.36 & 0.00 & 1.00 \\
\hline ROS (SD) & $\begin{array}{l}\text { This variable is calculated as the standard } \\
\text { deviation regarding the profit to sales ratio in } \\
\text { the period under review (1994-2003) and is } \\
\text { represented in terms of its natural logarithm. }\end{array}$ & $\ln$ & -3.06 & 1.33 & - & -0.51 \\
\hline $\begin{array}{l}\text { SAME } \\
\text { INDUSTRY }\end{array}$ & $\begin{array}{l}\text { This variable takes on the value of one where } \\
\text { the parent company and the subsidiary } \\
\text { belong to the same industry sector (NACE). } \\
\text { The value of zero is assigned if the industry } \\
\text { sectors differ. }\end{array}$ & Dummy & 0.36 & 0.48 & 0.00 & 1.00 \\
\hline
\end{tabular}

\footnotetext{
a The alternative specifications of LP are defined as dummy variables since they are applied for the purpose of differentiating treatment group and control group in our difference-in-difference regression model

${ }^{\mathrm{b}}$ In order to limit the influence of outliers return on sales ratios of more than plus $100 \%$ and less than minus $100 \%$ were eliminated
} 
correlated with the post-reform dummy REFORM and therefore had to be excluded. ${ }^{20}$ The resulting regression model reads as follows:

$p($ Organschaft $=1)=\frac{e^{z}}{1+e^{z}}$, with

$$
\begin{aligned}
z & =b_{0}+b_{1} \cdot \text { REFORM }+b_{2} \cdot \text { TREATMENT }+b_{3} \cdot \text { REFORM } \cdot \text { TREATMENT } \\
& +b_{4} \cdot \text { ENTERPRISE }+b_{5} \cdot \text { GROUP SIZE }+b_{6} \cdot \text { MIN_SH } \\
& +b_{7} \cdot \text { MIN_SH } \cdot \text { ENTERPRISE }+b_{8} \cdot \operatorname{ROS}(\mathrm{SD})+b_{9} \cdot \text { SAME INDUSTRY }+\varepsilon .
\end{aligned}
$$

The dummy variable TREATMENT stands for the treatment group of the 2001 tax reform quasi-experiment. We distinguish alternative definitions of TREATMENT in order to account for the fact that the tax reform amended both the tax advantages of, and the prerequisites for, entering into a tax group. ${ }^{21}$ In a first setting, subsidiaries negatively affected by the fact that in standard groups losses cannot be offset vertically downward after the tax reform function as the treatment group. These are subsidiaries with a value of one for the LP variable. For this group the reform increased the tax advantages resulting from implementing a tax group, which leads to the expectation of a positive value for $b_{3}$. The corresponding control-group comprises those companies for which the LP variable takes a value of zero meaning that the tax reform did not extend the tax advantages of implementing a tax group. In defining the LP variable we distinguish three different specifications reflecting thresholds of 30,50 and $80 \%$ of all years in which the profit and loss situation in a group has to be of the relevant type (parent company losses and subsidiary profits) for the LP variable to take the value of one. This accounts for the fact that companies might not be influenced in their decision as to whether to opt for a tax group or not if the occurrence of profits and losses being spread in this manner turns out to be a single event.

Apart from extending the tax advantages of a tax group with respect to loss-offset a further consequence of the 2001 tax reform was that the prerequisites for forming a tax group were relaxed. This amendment might affect small subsidiaries differently to large subsidiaries assuming that the stricter prerequisites prior to the reform deterred especially these companies from entering into a tax group. The same applies to subsidiaries with minority shareholders for which the verification of organizational and economic integration as required prior to the reform should have been more difficult than for wholly owned subsidiaries. We therefore estimate additional regression models with the treatment group of the reform being defined as small companies (ENTERPRISE $=1$ ) and companies with minority shareholders

\footnotetext{
${ }^{20}$ The correlation between REFORM and GDP takes on the value of -0.944 . The latter variable is measured as the average growth of real GDP in the years for which AMADEUS provides data for the subsidiary during the relevant period under consideration (1994 to 2000 or 2001 to 2003 respectively).

21 See Sect. 2.2 for a discussion concerning the impact of the 2001 tax reform on the decision to opt for a tax group.
} 
$\left(\right.$ MINORITY $\left.=1^{22}\right)$, respectively, expecting positive difference-in-difference estimators in both cases.

\subsubsection{Regression results}

Table 8 presents the regression results for the treatment group defined with regard to the variable LP, reflecting the scenario that the parent company incurs losses while the subsidiary is profitable. Specifications (1)-(3) are based on the logistic regression model as set out above and apply the different thresholds of 30, 50 and $80 \%$ for the determination of LP. Specification (4) applies a linear probability model to Panel 1, whereas specification (5) applies the logistic regression model to Panel 2, both being estimated for robustness check purposes. Applying the regression model to Panel 2 helps to reduce the extent to which the regression may be distorted by the fact that companies in the sample did not qualify as subsidiaries throughout the whole period under consideration.

The results for the estimation of specifications (1)-(3) indicate that-as expected in hypothesis 1 (Sect. 2.4) - the probability for subsidiaries entering into a tax group increased significantly after the tax reform. The odds ratio for the probability of entering into a tax group is increased by the factor $e^{0.636}=1.89$ [specification (3)] if REFORM takes up a value of one. However, due to the exogenous shock of the economic downturn taking place at the same time we cannot unambiguously assign this effect to the fact that the tax group prerequisites were relaxed. The positive coefficient for REFORM*TREATMENT, however, reveals that the probability for entering into a tax group was increased to a greater extent for companies belonging to the treatment group than for companies belonging to the control group. This result confirms hypothesis 2 as set out in Sect. 2.4. Both the size of this effect and its significance depend on the threshold applied for defining LP. If a threshold of $80 \%$ is applied, ${ }^{23}$ the odds ratio is significantly increased by the factor $e^{0.549}=1.73$ for companies belonging to the treatment group as compared to companies that are part of the control group. A lower threshold gives rise to a reduced impact of the reform on the decision made by companies in the treatment group, given a smaller increase of the odds ratios by the factor $e^{0.408}=1.50$ and $e^{0.327}=1.39$ respectively. In both specifications, the estimator for REFORM*TREATMENT turns out to be less significant.

Irrespective of the influence exerted by the tax reform, our analysis indicates, that as a rule, both costs and liability risks associated with concluding a profit and loss transfer agreement deter companies from entering into a tax group (see hypotheses 6 and 7 as set out above). In this context, the odds ratio is reduced significantly by the factor $e^{-0.030}=0.970^{24}$ for each percent held in the subsidiary by minority

\footnotetext{
${ }^{22}$ In these regression models the interaction term MINORITY*ENTERPRISE is included instead of MIN_SH*ENTERPRISE.

23 This means that companies are only included in the treatment group if the scenario of the parent company incurring losses and the subsidiary being profitable occurs in at least 80 percent of all years.

24 Value refers to specification (3).
} 
Table 8 Regression results (1)

\begin{tabular}{|c|c|c|c|c|c|}
\hline $\begin{array}{l}\text { Panel } \\
\text { TREATMENT } \\
\text { Regression }\end{array}$ & $\begin{array}{l}(1) \\
\text { Panel 1 } \\
\text { LP_30 } \\
\text { Logistic }\end{array}$ & $\begin{array}{l}(2) \\
\text { Panel } 1 \\
\text { LP_50 } \\
\text { Logistic }\end{array}$ & $\begin{array}{l}(3) \\
\text { Panel } 1 \\
\text { LP_80 } \\
\text { Logistic }\end{array}$ & $\begin{array}{l}(4) \\
\text { Panel } 1 \\
\text { LP_80 } \\
\text { Linear }\end{array}$ & $\begin{array}{l}(5) \\
\text { Panel } 2 \\
\text { LP_80 } \\
\text { Logistic }\end{array}$ \\
\hline REFORM & $\begin{array}{l}0.604 * * * \\
(0.102)\end{array}$ & $\begin{array}{l}0.603 * * * \\
(0.101)\end{array}$ & $\begin{array}{l}0.636 * * * \\
(0.085)\end{array}$ & $\begin{array}{l}0.140 * * * \\
(0.018)\end{array}$ & $\begin{array}{l}0.399 * * \\
(0.169)\end{array}$ \\
\hline TREATMENT & $\begin{array}{l}0.147 \\
(0.134)\end{array}$ & $\begin{array}{l}0.243 * \\
(0.146)\end{array}$ & $\begin{array}{l}0.423 * * \\
(0.195)\end{array}$ & $\begin{array}{l}0.090 * * \\
(0.042)\end{array}$ & $\begin{array}{l}1.131 \\
(0.760)\end{array}$ \\
\hline REFORM* TREATMENT & $\begin{array}{l}0.327 * * \\
(0.155)\end{array}$ & $\begin{array}{l}0.408 * * \\
(0.169)\end{array}$ & $\begin{array}{l}0.549 * * * \\
(0.200)\end{array}$ & $\begin{array}{l}0.132 * * * \\
(0.043)\end{array}$ & $\begin{array}{l}0.157 \\
(0.633)\end{array}$ \\
\hline ENTERPRISE & $\begin{array}{l}-0.461 * * \\
(0.192)\end{array}$ & $\begin{array}{l}-0.453^{* *} \\
(0.115)\end{array}$ & $\begin{array}{l}-0.446^{* *} \\
(0.119)\end{array}$ & $\begin{array}{l}-0.103^{* *} \\
(0.044)\end{array}$ & $\begin{array}{l}1.163 * * * \\
(0.393)\end{array}$ \\
\hline GROUP SIZE & $\begin{array}{l}0.025 \\
(0.045)\end{array}$ & $\begin{array}{l}0.033 \\
(0.045)\end{array}$ & $\begin{array}{l}0.033 \\
(0.046)\end{array}$ & $\begin{array}{l}0.007 \\
(0.010)\end{array}$ & $\begin{array}{l}0.018 \\
(0.084)\end{array}$ \\
\hline MIN_SH & $\begin{array}{l}-0.030 * * * \\
(0.003)\end{array}$ & $\begin{array}{l}-0.029 * * * \\
(0.004)\end{array}$ & $\begin{array}{l}-0.030 * * * \\
(0.004)\end{array}$ & $\begin{array}{l}-0.006 * * * \\
(0.001)\end{array}$ & $\begin{array}{l}-0.008 \\
(0.011)\end{array}$ \\
\hline MIN_SH *ENTERPRISE & $\begin{array}{l}0.001 \\
(0.010)\end{array}$ & $\begin{array}{l}0.001 \\
(0.010)\end{array}$ & $\begin{array}{l}0.001 \\
(0.011)\end{array}$ & $\begin{array}{l}0.001 \\
(0.002)\end{array}$ & $\begin{array}{l}-0.117 \\
(0.062)\end{array}$ \\
\hline PL & $\begin{array}{l}0.727 * * \\
(0.342)\end{array}$ & $\begin{array}{l}0.770 * * \\
(0.345)\end{array}$ & $\begin{array}{l}0.759 * * \\
(0.350)\end{array}$ & $\begin{array}{l}0.172 * \\
(0.081)\end{array}$ & $\begin{array}{l}0.601 \\
(0.542)\end{array}$ \\
\hline ROS (SD) & $\begin{array}{l}0.028 \\
(0.078)\end{array}$ & $\begin{array}{l}0.035 \\
(0.077)\end{array}$ & $\begin{array}{l}0.049 \\
(0.077)\end{array}$ & $\begin{array}{l}0.010 \\
(0.016)\end{array}$ & $\begin{array}{l}0.265^{*} \\
(0.144)\end{array}$ \\
\hline SAME INDUSTRY & $\begin{array}{l}-0.278 * \\
(0.149)\end{array}$ & $\begin{array}{l}-0.258 \\
(0.149)\end{array}$ & $\begin{array}{l}-0.259 * \\
(0.138)\end{array}$ & $\begin{array}{l}-0.057 * \\
(0.029)\end{array}$ & $\begin{array}{l}-0.694 * * * \\
(0.190)\end{array}$ \\
\hline Observations & 1,320 & 1,320 & 1,320 & 1,320 & 240 \\
\hline Percentages correctly predicted & 64.6 & 64.5 & 64.7 & & 62.5 \\
\hline Nagelkerkes $R^{2}$ & 0.117 & 0.122 & 0.128 & & 0.146 \\
\hline Adjusted $R^{2}$ & & & & 0.088 & \\
\hline \multicolumn{6}{|l|}{ Hosmer-Lemeshow } \\
\hline Chi Squared & 6.198 & 10.273 & 11.819 & & 6.007 \\
\hline Significance & 0.625 & 0.246 & 0.159 & & 0.646 \\
\hline
\end{tabular}

Dependent variable: TG. ***, $* *$ and $*$ denote significance at the 1,5 and $10 \%$ level respectively. Robust and clustered (industry clusters) standard errors are given in parentheses. A constant is used but not reported. Variables are largely uncorrelated $(<0.7)$; see the Appendix for a correlation matrix

shareholders. Being a small company further reduces the probability of entering into a tax group significantly. Amongst the variables that reflect the risk for the parent company of becoming liable for losses of the subsidiary [ROS(SD) and SAME INDUSTRY] only SAME INDUSTRY shows significant influence. The negative sign of the estimated coefficient gives indirect support hypothesis 8 in Sect. 2.4 that the probability of entering into a tax group is reduced with increasing risk of the subsidiary. 
The results of the regression analyses further demonstrate that-as expected-the manner in which profits and losses are spread amongst parent company and subsidiaries has significant influence on the decision to form a tax group for income tax purposes. Whereas the situation in which the parent company incurs losses while the subsidiary is profitable increases the probability for forming a tax group, especially after the tax reform-as seen above-the frequency of the opposite situation has a strong and significant positive influence, both in the period prior to and the period following the tax reform. The impact of these two different profit and loss constellations differs although the tax group advantages regarding intra-group loss offset are the same in both cases. If the parent company is profitable throughout the whole period under consideration whereas the subsidiary incurs losses in any period $(\mathrm{PL}=1)$, the odds ratio for entering into a tax group is increased by the factor $e^{0.759}=2.14 .^{25}$ In the case of the opposite constellation $($ LP_80 $=1)$ the odds ratio is increased by the factor $e^{0.549} * e^{0.423}=2.64$. The smaller impact arising in the case of the subsidiary incurring losses may be due to the higher liability risk associated with this constellation.

In order to assess the overall validity of the model applied, we report (a) Pseudo$R^{2}$ according to the formula recommended by Nagelkerke, (b) the portion of observations classified correctly by the model as standard group or tax group (hit ratio) and (c) the results of the Hosmer-Lemeshow test. Thereby, Nagelkerkes $R^{2}$ is reported as a goodness-of-fit statistic, whereas the hit ratio and the results of the Hosmer-Lemeshow test are reported in order to assess the ability of the model to classify subsidiaries correctly (see Nagelkerke 1991; Hosmer and Lemeshow 1989). The resulting values for Nagelkerkes $R^{2}$ between 11.7 and $12.8 \%$ are not unsatisfactorily low taking into account the complexity of the underlying company decision. The same holds true for the hit ratio, which takes values of 64.6, 64.5 and $64.7 \%$. The results of the Hosmer-Lemeshow test show no significant difference between the observed and the expected values in any of the three specifications, indicating that the model is appropriate to explain the use of a tax group. Furthermore, specifications (4) and (5) that are estimated for robustness-check purposes confirm most of the measured effects in their direction. Apart from a different sign for ENTERPRISE and MIN_SH*ENTERPRISE, differences arise only with regard to the size and the significance of the effects which in the case of specification (5) should be due especially to the much smaller number of companies included in the sample.

As outlined above, additional regression models are estimated with the treatment group of the reform being defined as small companies (ENTERPRISE $=1$ ) and companies with minority shareholders (MINORITY $=1$ ), respectively. In doing so, we test whether, and if so, to what extent the relaxation of the tax group prerequisites has been of particular impact for these companies. The results of these additional regressions as reported in Table $9,{ }^{26}$ however, do not support the

\footnotetext{
25 If PL is defined as a dummy similar to LP_80 the odds ratio would be increased by $e^{0.789}=2.20$.

26 Again, the results of the corresponding linear probability models are reported for robustness check purposes as specifications (3) and (4).
} 
Table 9 Regression results (2)

\begin{tabular}{|c|c|c|c|c|}
\hline $\begin{array}{l}\text { Panel } \\
\text { TREATMENT } \\
\text { Regression }\end{array}$ & $\begin{array}{l}(1) \\
\text { Panel } 1 \\
\text { ENTERPRISE } \\
\text { Logistic }\end{array}$ & $\begin{array}{l}(2) \\
\text { Panel } 1 \\
\text { MINORITY } \\
\text { Logistic }\end{array}$ & $\begin{array}{l}(3) \\
\text { Panel } 1 \\
\text { ENTERPRISE } \\
\text { Linear }\end{array}$ & $\begin{array}{l}(4) \\
\text { Panel } 1 \\
\text { MINORITY } \\
\text { Linear }\end{array}$ \\
\hline REFORM & $\begin{array}{l}0.708 * * * \\
(0.058)\end{array}$ & $\begin{array}{l}0.718 * * * \\
(0.121)\end{array}$ & $\begin{array}{l}0.162 * * * \\
(0.013)\end{array}$ & $\begin{array}{l}0.172 * * * \\
(0.028)\end{array}$ \\
\hline TREATMENT & $\begin{array}{l}-0.476 \\
(0.306)\end{array}$ & $\begin{array}{l}-0.676^{* * * *} \\
(0.174)\end{array}$ & $\begin{array}{l}-0.102 \\
(0.062)\end{array}$ & $\begin{array}{l}-0.136^{* * *} \\
(0.036)\end{array}$ \\
\hline REFORM* TREATMENT & $\begin{array}{l}0.057 \\
(0.251)\end{array}$ & $\begin{array}{l}0.018 \\
(0.248)\end{array}$ & $\begin{array}{l}-0.003 \\
(0.048)\end{array}$ & $\begin{array}{l}-0.031 \\
(0.054)\end{array}$ \\
\hline ENTERPRISE & & $\begin{array}{l}-0.302 \\
(0.243)\end{array}$ & & $\begin{array}{l}-0.071 \\
(0.056)\end{array}$ \\
\hline GROUP SIZE & $\begin{array}{l}0.033 \\
(0.045)\end{array}$ & $\begin{array}{l}0.035 \\
(0.048)\end{array}$ & $\begin{array}{l}0.007 \\
(0.010)\end{array}$ & $\begin{array}{l}-0.008 \\
(0.011)\end{array}$ \\
\hline MIN_SH & $\begin{array}{l}-0.029 * * * \\
(0.004)\end{array}$ & & $\begin{array}{l}-0.006^{* * * *} \\
(0.001)\end{array}$ & \\
\hline MN_SH *ENTERPRISE & $\begin{array}{l}0.001 \\
(0.010)\end{array}$ & & $\begin{array}{l}0.001 \\
(0.002)\end{array}$ & \\
\hline MINORITY *ENTERPRISE & & $\begin{array}{l}-0.554 * * \\
(0.263)\end{array}$ & & $\begin{array}{l}-0.073 \\
(0.058)\end{array}$ \\
\hline PL & $\begin{array}{l}0.765 * * \\
(0.353)\end{array}$ & $\begin{array}{l}0.724 * * \\
(0.341)\end{array}$ & $\begin{array}{l}0.172 * \\
(0.081)\end{array}$ & $\begin{array}{l}0.163 * \\
(0.079)\end{array}$ \\
\hline LP_80 & $\begin{array}{l}0.698 * * * \\
(0.205)\end{array}$ & $\begin{array}{l}0.665^{* * * *} \\
(0.203)\end{array}$ & $\begin{array}{l}0.156^{* * * *} \\
(0.047)\end{array}$ & $\begin{array}{l}0.150 * * * \\
(0.048)\end{array}$ \\
\hline $\operatorname{ROS}(\mathrm{SD})$ & $\begin{array}{l}0.049 \\
(0.077)\end{array}$ & $\begin{array}{l}0.054 \\
(0.077)\end{array}$ & $\begin{array}{l}0.010 \\
(0.016)\end{array}$ & $\begin{array}{l}0.011 \\
(0.016)\end{array}$ \\
\hline SAME INDUSTRY & $\begin{array}{l}-0.259^{*} \\
(0.138)\end{array}$ & $\begin{array}{l}-0.202 \\
(0.136)\end{array}$ & $\begin{array}{l}-0.057^{*} \\
(0.029)\end{array}$ & $\begin{array}{l}-0.044 \\
(0.030)\end{array}$ \\
\hline Observations & 1,320 & 1,320 & 1,320 & 1,320 \\
\hline Percentages correctly predicted & 64.1 & 65.3 & & \\
\hline Nagelkerkes $R^{2}$ & 0.126 & 0.125 & & \\
\hline Adjusted $R^{2}$ & & & 0.085 & 0.085 \\
\hline \multicolumn{5}{|l|}{ Hosmer-Lemeshow } \\
\hline Chi Squared & 10.713 & 5.67 & & \\
\hline Significance & 0.219 & 0.684 & & \\
\hline
\end{tabular}

Dependent variable: TG.***, $* *$ and $*$ denote significance at the 1,5 and $10 \%$ level respectively. Robust and clustered (industry clusters) standard errors are given in parentheses. A constant is used but not reported. Variables are largely uncorrelated $(<0.7)$; see the Appendix for a correlation matrix

expectations as set out above. The estimator for the interaction term REFORM*TREATMENT emerges as being insignificant for both definitions of the treatment group and for both the logistic and linear models. 


\section{Conclusion}

The focus of this paper is on the determinants of opting for the German group taxation regime with regard to taxes on corporate profits. As has been shown above, meeting the requirements of a tax group brings tax advantages on the one hand, and non-tax disadvantages in terms of costs and the assumption of liability risks on the other, for the companies concerned. The question therefore arose as to the kind of companies choosing not to exploit the tax advantages inherent to using a tax group, and the extent to which this is the case. Furthermore, the paper addresses the question as to whether, and if so to what extent, the 2001 German tax reform has affected this company decision.

Our regression analysis reveals that companies tend to make use of the tax group option especially where tax benefits are substantial. In the case of less apparent tax benefits the use of the instrument is less widespread. Since the advantages of forming a tax group were enhanced with the introduction of the exemption method and the prerequisites for forming a tax group were relaxed at the same time, the probability of entering into a tax group increased significantly as from 01.01.2001. This holds true especially for companies that benefit from the enhanced tax advantages under the tax group regime as introduced in 2001. Significant factors hindering companies from forming a tax group turned out to be the company size and the existence of minority shareholders. Being not wholly owned or being a small company reduces significantly the odds ratio for subsidiaries entering into a tax group.

Altogether, the percentage of controlled companies amounts to only around $30 \%$ of eligible companies meeting the requisite participation threshold. Although it has to be borne in mind that the factors influencing the decision to form a tax group are not covered in their entirety by our results, we nevertheless conclude that the "price" of meeting the tax group requirement to enter into a profit and loss transfer agreement is, for many companies, too high. If the requirement of this agreement were to be abolished on the grounds of facilitating access to the benefits of group taxation, this would therefore signify the removal of a major obstacle to forming a tax group. To what extent the removal of this obstacle would result in more intensive use of the tax group option remains to be investigated. This subject for future research requires data providing evidence on how companies perceive the increased liability risk that is associated with entering into a profit and loss transfer agreement.

Acknowledgments The authors wish to thank the two reviewers for their helpful and valuable comments which led to a substantial improvement of the paper in its revised form.

Open Access This article is distributed under the terms of the Creative Commons Attribution Noncommercial License which permits any noncommercial use, distribution, and reproduction in any medium, provided the original author(s) and source are credited.

\section{Appendix}

See Table 10. 


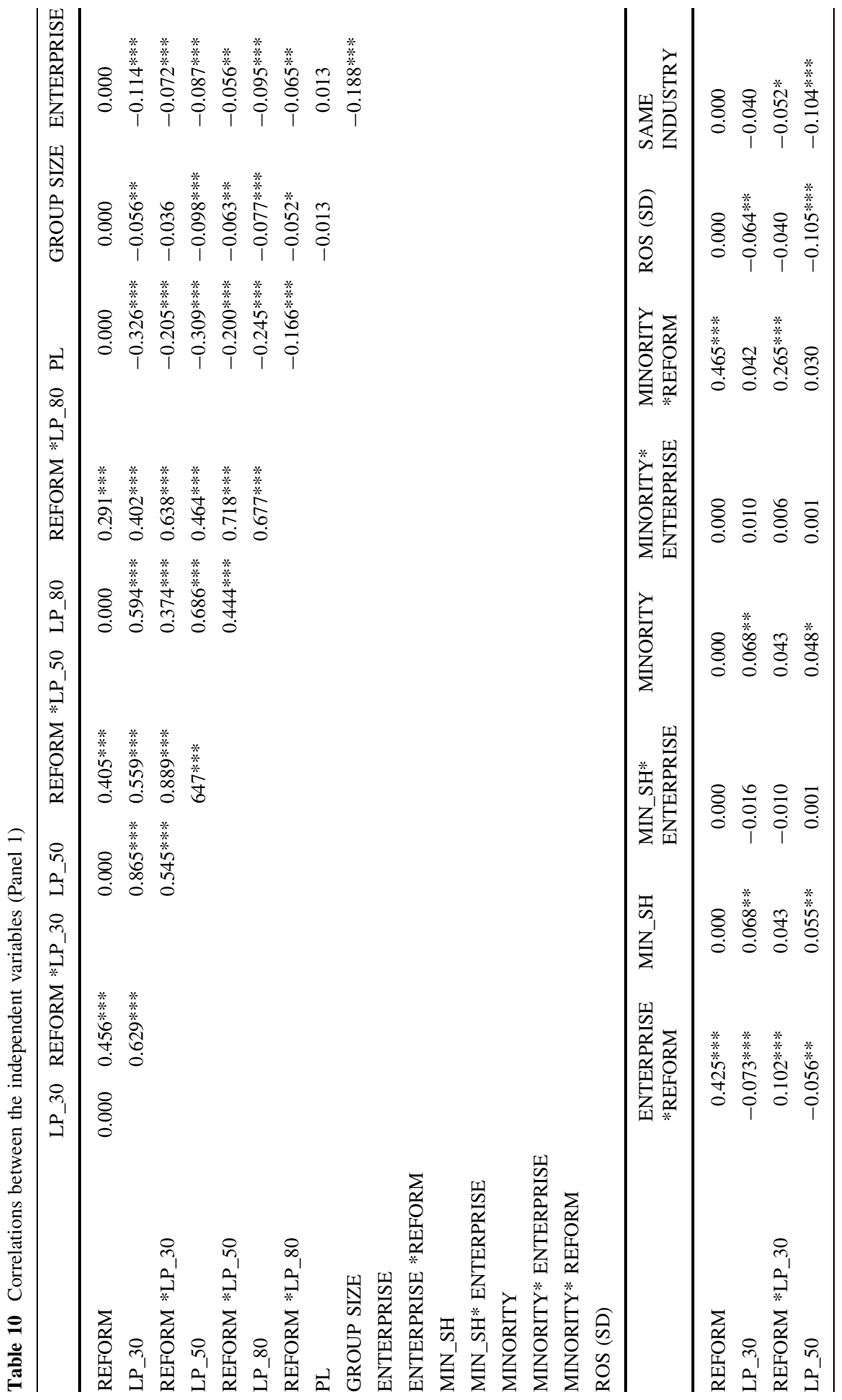




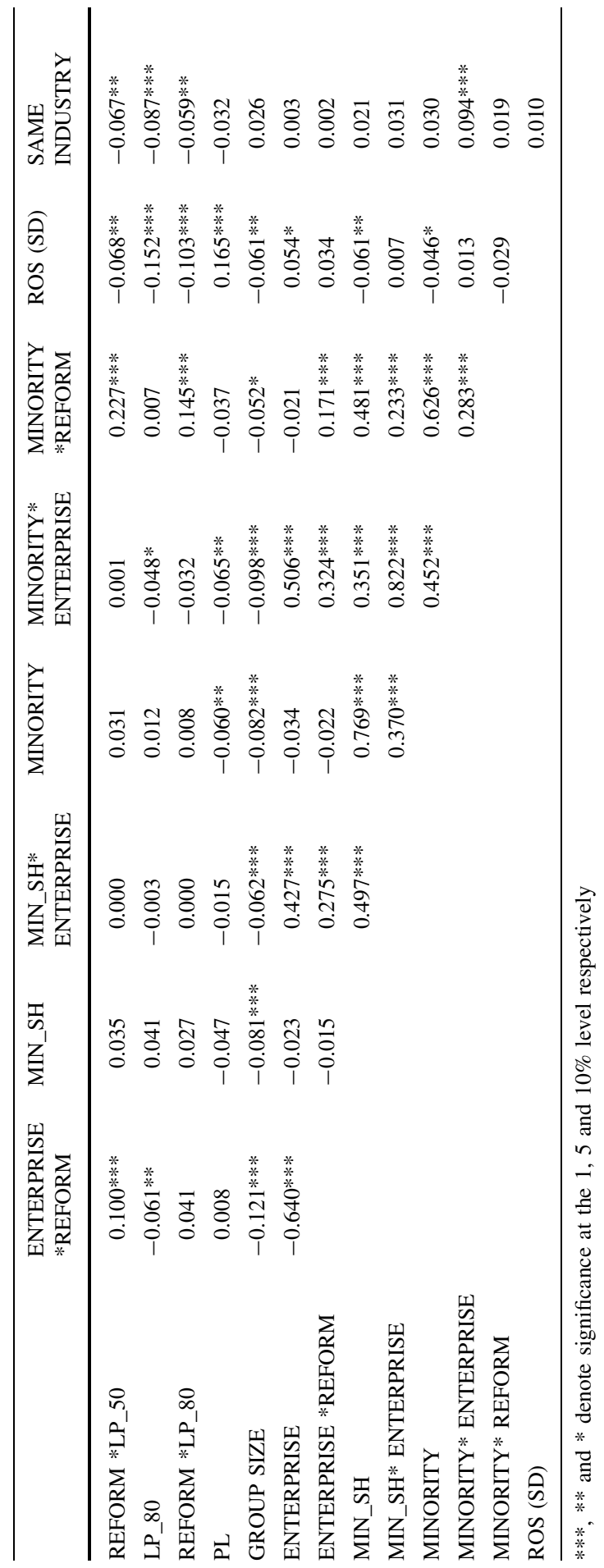




\section{References}

Altshuler R, Auerbach AJ (1990) The significance of tax law asymmetries: an empirical investigation. Q J Econ 105:63-86

Auerbach AJ, Poterba JM (1986) In: Martin F (ed) The effects of taxation on capital accumulation 1987:305-342

Büttner T, Riedel N, Runkel M (2008) Strategic consolidation under formula apportionment, CESifo Working Paper Nr. 2484

Commission of the European Communities (2001) Commission Staff Working Paper, Company Taxation in the Internal Market, Brussels, 23.10.2001/SEC(2001)1681, COM(2001)582 final

Commission of the European Communities (2006) Communication from the European Commission to the Council, the European Parliament and the European Economic and Social Committee, Brussels, 19.12.2006, $\operatorname{COM}(2006) 825$ final

Commission of the European Communities, CCCTB WG (2007) CCCTB: possible elements of a technical outline, CCTB/WP057annotatedldoclen, Brussels, 26 July 2007, Taxud E1, No. 20

Desai MA, Foley CF, Hines JR Jr (2004) The costs of shared ownership: evidence from international joint ventures. J Financ Econ 73:323-374

Deutsche Bundesbank (2006) Verhältniszahlen aus Jahresabschlüssen deutscher Unternehmen von 2002 bis 2003, Frankfurt/Main

Endres D et al (2007) The determination of corporate taxable income in the EU Member States, Alphen aan den Rijn

European Court of Justice (2008a) Judgment of the Court (Third Chamber) of 22 May 2008, Case C-439/ 06, Citiworks AG (Sächsisches Staatsministerium für Wirtschaft und Arbeit) v Flughafen Leipzig/ Halle GmbH and Bundesnetzagentur, OJ C 171, 5.7.2008, 6

European Court of Justice (2008b) Judgment of the Court of Justice (Fourth Chamber) of 23 October 2008, Case C-157/07, Finanzamt für Körperschaften III in Berlin v Krankenheim Ruhesitz am Wannsee-Seniorenheimstatt GmbH, OJ C 313, 6.12.2008, 5

European Court of Justice, Judgment of the Court of Justice (Grand Chamber) dated 13 December 2005, Case C-446/03, Chancery Division Marks \& Spencer plc v David Halsey (Her Majesty's Inspector of Taxes), OJ C 36, 11.2.2006, 5

Gentry WM (1994) Taxes, financial decisions and organizational form, evidence from publicly traded partnerships. J Public Econ 53:223-244

Gérard M, Weiner JM (2003) Cross-border loss offset and formulary apportionment: how do they affect multijurisdictional firm investment spending and interjurisdictional tax competition? CESifo Working Paper No. 1004

Hosmer D, Lemeshow S (1989) Applied logistic regression, New York

Jacobs OH (2007) Internationale Unternehmensbesteuerung, 6th edn, Munich

Nagelkerke NJD (1991) A note on a general definition of the coefficient of determination. Biometrica 78:691-692

Oestreicher A, Koch R (2008) Corporate average tax rates under the CCCTB and possible methods for international loss-offset, Working Paper No. 08-001, Georg-August-Universität Göttingen

Orth M (2005) Die Bedeutung des Gewinnabführungsvertrags für die Besteuerung des Konzernerfolgs. In: Oestreicher A (ed) Konzernbesteuerung, Herne, Berlin, pp 129-195

Overesch M, Wamser G (2009) Corporate tax planning and thin-capitalization rules: evidence from a Quasi-experiment. Appl Econ (forthcoming)

Prinz U (2003) Wirtschaftliche Konsequenzen der Organschaft. In: Herzig N (Hrsg) Organschaft, Stuttgart, pp 545-561

Sureth C, Üffing M (2008) Proposals for a European corporate taxation and their influence on multinationals' tax planning, arqus discussion papers in Quantitative Tax Research, No. 54

Weichenrieder A, Mintz J (2008) What determines the use of holding companies and ownership chains? Oxford University Centre for Business Taxation Working Paper 08/03 